\title{
BONAPARTE E O IMAGINÁRIO LITERÁRIO PORTUGUÊS
}

\section{THE ROLE OF NAPOLEON BONAPARTE IN PORTUGUESE LITERATURE}

Leonardo Atayde Pereira

Doutor em Estudos Comparados de Literaturas de Língua Portuguesa pela Universidade de São Paulo. 
Resumo: A figura emblemática de Napoleão Bonaparte ocupou um papel de indiscutível relevância dentro do contexto histórico e, por conseguinte, suas ideias e atitudes como general, político e revolucionário foram constantemente retomadas e interpretadas por uma série de historiadores e intelectuais ao longo do período oitocentista. Essa ação interpretativa em torno de Bonaparte e do seu legado ideológico também marcou presença na prosa historiográfica e literária portuguesa durante o século XIX e início do XX, em destaque para alguns trabalhos de Garrett, Herculano, Camilo e Antônio Maria de Campos Júnior, autores analisados dentro de suas particularidades estéticas no presente artigo.

Palavras-chave: Bonaparte, romance histórico, literatura portuguesa, Revolução Francesa, exílio. 
Abstract: The emblematic figure of Napoleon Bonaparte played a role of undoubted relevance within his historical contexto and, subsequently, his ideas and atitudes as general, politician, and revolutionary were constantly taken up and interpreted by several historians and intellectuals throughout the 19th century. The interpretative action about Bonaparte and his ideological legacy were also present in portuguese historiographical and literary prose during the 19th and early 20th centuries, highlighting some publications of Garrett, Herculano, Camilo and Antônio Maria de Campos Júnior analyzed regarding their aesthetic particularities in the presente manuscript.

Keywords: Bonaparte, historical novel, Portuguese literature, French Revolution, exile. 


\section{A construção da imagem política de Napoleão Bonaparte}

A trajetória militar e política de Napoleão Bonaparte (1769-1821) foi intensa, rápida e grandiosa. De acordo com seus biógrafos, Napoleão iniciou a carreira militar em 1785 no posto de segundo tenente e, como é de conhecimento de todos, em 1804 se tornou Imperador da França.

Esse caminho ímpar e bem sucedido de conquistas políticas e glórias militares fez com que o nome do general oriundo da Córsega se transformasse, sem dúvida nenhuma, entre todos os personagens históricos envolvidos com a Revolução Francesa, no mais conhecido do público em geral, e dotado de uma capacidade em despertar empatia e admiração na mesma intensidade que estimulava temor, aversão e ódio.

Por concentrar variadas e discordantes leituras ideológicas e simbólicas ao longo do tempo, a figura emblemática de Napoleão Bonaparte foi revisitada muitas vezes tanto pela historiografia quanto pela narrativa ficcional, contemporâneas ao seu contexto histórico e atuais.

Esse contínuo movimento de construção e desconstrução da figura de Napoleão Bonaparte fez com que surgissem diferentes linhas interpretativas sobre o percurso pessoal, militar e político do general que foi coroado Imperador dos franceses. Contudo, apesar dessas leituras díspares acerca de Bonaparte, 
todas elas, de alguma maneira, contribuíram para a formação de um mito napoleônico deflagrado no imaginário político oitocentista e intensificado ao longo dos anos, seja na literatura, no cinema ou nos currículos escolares.

A mitologização da personagem de Napoleão Bonaparte também se fez presente no imaginário político ibérico do século XIX. Sobre esse tema cabe destacar as contribuições da pesquisadora brasileira Lúcia Bastos Pereira das Neves, que trabalhou amplamente com a construção das representações napoleônicas em Portugal entre os anos de 1808 e 1810, analisando, entre fontes documentais, panfletos políticos produzidos no período, majoritariamente antinapoleônicos e dotados de uma grande riqueza simbólica.

Na Península Ibérica, surgiram também figuras alegóricas sobre o domínio napoleônico, representando-o enquanto o dragão e a besta do Apocalipse ou em uma viagem aos infernos, demonstrando que a persistência de símbolos de inspiração bíblica era um recurso amplamente utilizado pela linguagem política, constituindo um traço marcante da cultura política do período nessa região. (NEVES, 2008, p.52)

A autora ressalta que as mudanças na tônica das adjetivações em torno da figura de Napoleão Bonaparte variaram conforme o contexto histórico no qual estavam inseridas e nos objetivos ideológicos que pretendiam defender e propagar. Para grande parte dos portugueses do período das invasões napo- 
leônicas, Bonaparte representava a ruptura do mundo tradicional da religião e das convenções políticas do Antigo Regime.

Essa lenda negra (NEVES, 2008, p. 52) que transformou Napoleão num tirano cruel, degenerado e usurpador em Portugal foi alimentada pelos setores sociais que não se reconheciam nos novos valores políticos, sociais e culturais promovidos pelo furor revolucionário da Revolução Francesa e difundidos, posteriormente, também pelas conquistas napoleônicas.

Apesar de Bonaparte carregar consigo a imagem de tirano e de homem demoníaco, projetou, na mesma medida, a exteriorização ideológica de uma nova sociedade, calcada na força de realização pessoal do indivíduo, na secularização da política e no fim dos privilégios de nascimento, alimentando, dessa forma, a esperança daqueles que clamavam por mudanças e mais justiça.

Com a coroação de Napoleão, em 1804, muitos entusiastas do talentoso general, como o músico e compositor Ludwig van Beethoven (FALBEL, 2011, p. 41), Benjamin Constant e Madame de Stael, afastaram-se do culto de admiradores de Bonaparte enxergando apenas um indivíduo comum, conduzido por ambições pessoais e excessivamente orgulhoso.

Contudo, para outros, o fato de Napoleão Bonaparte ter se coroado Imperador dos franceses, só corroborou com o aumento do fascínio exercido pela sua figura e pelo poder do seu protagonismo. Para o 
nascente século XIX, temporalmente conduzido por uma visão de mundo romântica, Napoleão representou o indivíduo que através de sua inesgotável vontade promovia a transformação do mundo ao seu redor, corporificando e cristalizando a imagem do herói romântico.

Durante o poder, as vitórias e as derrotas, a guerra e a paz, contribuíram para transformar o panorama político europeu e, mais ainda, ajudaram à emergência de novos Estados nacionais inspirados, de um lado, nas ideias revolucionárias e, de outro, nas tradições culturais e populares despertadas em nacionalidades que haviam recém-descoberto a sua consciência nacional e ambicionavam um lugar ao sol entre as nações. (FALBEL, 2011, p. 41)

A imagem auspiciosa de Bonaparte, conhecida como lenda rosa ou dourada, consolidada principalmente na França entre 1800 e 1814 (NEVES, 2008, p.42), teve alguns adeptos ilustres em Portugal, como Pedro José de Almeida Portugal, o Marquês de Alorna, e Manuel Inácio Martins Pamplona, que participaram da la grande Armée napoleônica, serviram ao Imperador na campanha da Rússia e apoiaram os franceses na tentativa de reconquista do território português, entre 1810 a 1811, após a expulsão de Junot e do exército napoleônico de Portugal, a partir da Convenção de Sintra de 30 de agosto de 1808 (NEVES, 2008, p. 111). 
Após a batalha de Waterloo, em 18 de julho de 1815 , as ações políticas promovidas pela Santa Aliança (FALBEL, 2011, p. 44) tentaram sufocar e abafar as amplas transformações promovidas pelas guerras napoleônicas por meio da recondução aos tronos nacionais das antigas dinastias afetadas por Napoleão Bonaparte e através da intensa divulgação de panfletos e memórias políticas que tinham por objetivo sedimentar no imaginário oitocentista a lenda negra napoleônica.

Contudo, essa ampla propaganda política reacionária rapidamente perdeu adeptos, já que a população europeia passou a viver um clima antiliberal com medidas impopulares que tinham por objetivo reverter as transformações políticas e sociais promovidas sob o peso ideológico da experiência política revolucionária francesa.

A fermentação política caracteriza o período a partir de 1815. Espanha, Portugal, Piemonte e Nápoles, inspirados na tentativa fracassada da Espanha, de conseguir uma Constituição em 1812, se veem envoltos por agitações e revoltas que estouram nos anos de 18201821. Os revoltosos exigem constituições democráticas para os seus países e reinos. (FALBEL, 2011, p. 45)

Na França, a Restauração de Luís XVIII e de Carlos X (FALBEL, 2011, p. 47) só contribuiu para a popularização da lenda dourada napoleônica e, ampliada, 
ainda mais, após a morte do general corso no exílio de Santa Helena, em 05 de maio de 1821.

O mito do imperador liberal suplantava a figura presente do rei absoluto. Invertiam-se apenas os papéis o bem, agora, era representado por Napoleão e o mal, por Luís XVIII. A morte do imperador, em 05 de maio de 1821, trouxe de volta a imagem do herói, que, por ser homem, merecia o perdão, um perdão que a França tinha interesse em conceder para reviver os anos de glórias imperiais. Bonaparte voltava uma vez mais à memória dos franceses e dos europeus. Em primeiro lugar, por meio do novo herói edificado pelos românticos e pelos seus admiradores, (...). Em segundo, quando do retorno de suas cinzas, em 1840, para ocupar um lugar no Panteon entre os fundadores da nação (...). (NEVES, 2008, p. 135-136)

Em Portugal, a política da Santa Aliança igualmente não alcançou o sucesso almejado, além da irreversível transformação estrutural histórica promovida pela Revolução Francesa e ampliada pelas guerras napoleônicas, o príncipe português estava ausente. D. João governava a partir da colônia americana e o descontentamento em relação à intervenção inglesa no reino só dificultava, ainda mais, a restauração de uma ordem absolutista em terras portuguesas.

O sentimento de desamparo vivenciado pelos reinóis teve como maiores consequências a eclosão da revolta de 1817, promovida por Gomes Freire de Andrade, antigo combatente da Legião Portuguesa 
napoleônica, e a Revolta Liberal do Porto, em 1820 (BERBEL, 1997, pp. 31 e 32).

Contudo, ofantasma de Bonaparte não se manifestou apenas na insurreição de Gomes Freire, mas também esteve presente na revolta de Pernambuco ocorrida no Brasil igualmente no ano de 1817. De acordo com alguns historiadores, existiu um suposto plano, articulado entre ex-oficiais do exército napoleônico exilados nos Estados Unidos, como José Bonaparte, e lideranças da revolta pernambucana, de libertar Napoleão da prisão em Santa Helena e levá-lo para o Brasil (NEVES, 2008, p. 113). Esse episódio, ainda repleto de lacunas e pouco estudado pela historiografia, contou com a presença de ex-oficiais napoleônicos que desembarcaram no Nordeste nessa época e que foram interrogados pelo governo brasileiro.

Independente da veracidade e do real intuito dessa conspiração napoleônica abordada por Lúcia Maria Bastos Pereira das Neves fica clara a dimensão e o alcance do mito de Bonaparte em terras coloniais e reinóis após a derrota do general corso em Waterloo. Cabe também destacar a admiração que o imperador brasileiro D. Pedro I sentia por Napoleão, fascínio presente, por exemplo, na idealização da sua coroação e no registro do episódio pelo pintor Debret, discípulo de David, retratista oficial de Napoleão.

O imaginário político ibérico oitocentista, seja através de panfletos ou memórias políticas, elaborado por anônimos ou por figuras eminentes absorveu 
as diversas construções históricas de Bonaparte, elaboradas ao longo do século XIX nos países europeus envolvidos no contexto das guerras napoleônicas. Ao lado dessa literatura panfletária política, a narrativa ficcional oitocentista, por inúmeras vezes, soube explorar, intensamente, essa emblemática personalidade histórica.

A atração exercida por Napoleão quase se tornou um topo literário na produção ficcional elaborada após o evento das guerras napoleônicas, e da mesma maneira que as fontes documentais pesquisadas por Lúcia Maria Bastos Pereira das Neves apresentam visões diferentes sobre o general corso. A ficção da época ora contribui para a divulgação do imaginário napoleônico ligado à lenda dourada ora se refugia na vertente interpretativa da lenda negra.

Para citar somente o caso francês, autores como Victor Hugo, Alexandre Dumas, Stendhal, Balzac, Musset, Vigny e Nerval, citaram a figura de Napoleão Bonaparte inúmeras vezes nos seus escritos ou através de referências diretas ao longo do enredo ou como grande modelo e referência ideológica na construção dos personagens. Para os autores que compactuavam de uma visão de mundo romântica e para seus heróis ficcionais, cansados de uma vida monótona e triste imposta pela sociedade burguesa, Napoleão, com suas glórias, conquistas e seu ímpeto apaixonante, era, indubitavelmente, fascinante. 
Em Portugal, a construção de um imaginário literário em torno das guerras napoleônicas foi substancialmente ampla, como já pontuou a pesquisadora portuguesa Maria de Fátima Marinho no seu artigo "Quem tem medo dos franceses?". A autora, nesse texto, teve por objetivo central discutir a intrínseca relação existente entre a literatura francesa e a literatura portuguesa oitocentista nos seus pontos de convergências e discordâncias e, rapidamente, faz uma enumeração bibliográfica dos textos que, ao longo do tempo, abordaram a temática das invasões napoleônicas no território português.

(...) sobre a invasão de Junot, destacamos Carlota Ângela, de Camilo Castelo Branco (1858), A Casa dos Fantasmas, de Rebelo da Silva (1865), Os Guerrilheiros da Morte, de Pinheiro Chagas (1872), Paixão de Maria do Céu, de Carlos Malheiro Dias (1902), o 1o volume de A Filha do Polaco, de Campos Júnior (1903), (...); a invasão de Soult aparece nos romances de Camilo Castelo Branco, Onde Está a Felicidade? (1856), Carlota Ângela (1858), A Enjeitada (1865) e O Demônio do Ouro (1873-4), de Arnaldo Gama, O Sargento-Mor de Vilar (1863) e O Segredo do Abade (1864), de Pinheiro Chagas, Os Guerrilheiros da Morte (1872), de Alberto Pimentel, O Anel Misterioso (1873), de Campos Júnior, $2^{\circ}$ e $3^{\text {o }}$ volumes de $A$ Filha do Polaco (1903) (...); a invasão de Massena é referida em $O$ Anel Misterioso, de Alberto Pimentel (1873), nos 3o e 4o volumes de $A$ Filha do Polaco, de Campos Júnior (1903) (...). (MARINHO, 2011-12, p. 47-48)

Infelizmente, a pesquisadora apenas faz breves considerações sobre as representações literárias que 
as tropas francesas adquirem nesses relatos ficcionais de evidentes tonalidades históricas e não aborda como a figura de Napoleão Bonaparte se apresenta nessas obras. Seria instigante realizar uma análise futura desses escritos de valores literários diversos, que contribuiriam, sem dúvida, para uma tentativa de construção das representações napoleônicas feitas pela produção literária portuguesa ao longo dos séculos XIX e início do XX.

O levantamento bibliográfico ficcional realizado por Maria de Fátima Marinho, juntamente com os panfletos políticos analisados por Lúcia Maria Bastos Pereira das Neves, nos mostra como a imagem política de Bonaparte em Portugal foi constantemente reconfigurada a partir de um espaço cultural comum (MARINHO, 2011, p. 45) europeu e como um estudo mais sistemático dessa problemática histórica se faz urgente no intuito de compreender melhor a dinâmica temática literária portuguesa.

\section{Desdobramentos literários portugueses acerca de Bonaparte}

Almeida Garrett, paradigmático autor da prosa oitocentista portuguesa, no seu conhecido trabalho Portugal na Balança da Europa, exalta o caráter singular e providencial de Napoleão no andamento histórico da Revolução Francesa. Para ele, Bonaparte compeliu um equilíbrio e uma ordem ao caos da situação revo- 
lucionária francesa, contudo, na sua ânsia por glórias e conquistas, acabou dominando nações de maneira tirânica e, traiu o povo europeu, se aproximando dos antigos reis despóticos.

Mesmo desabonando, por um momento, a imagem de Napoleão, principalmente aquela do período imperial, Garrett, entretanto, enxergou a complexidade histórica das guerras napoleônicas e a compreensão de suas dinâmicas. Numa espécie de julgamento final, o escritor português pontua como o ímpeto conquistador de Bonaparte estimulou, de alguma maneira, a cristalização dos valores liberais da Revolução Francesa em diferentes locais do continente europeu.

Não defraudemos a glória militar do maior capitão da Terra, de seus grandes generais, de suas bravas legiões; não presumamos negar o que todo o mundo confessou com terror e submissão; - mas digamos, porque é verdade, que muitas de suas vitórias, e mormente as primeiras, as deveu à cooperação eficaz dos povos, que desejavam, que pediam ser conquistados: - tal era a aflição e descontento em que toda a Europa vivia! Enquanto os pendões tricolores anunciaram liberdade, nunca acharam resistência nos povos, antes de muitos foram invocados, - de todos seriam bem recebidos. (...)

Mas ao passo que as Águias francesas discorriam a Europa, já não para levar liberdade como o antigo estandarte do primeiro cônsul, mas em busca de presa e conquista para suas garras imperiais, a civilização vinha com elas disfarçada e como de contrabando; com elas penetrou nos mais obscuros recessos da Europa, até onde mais embrutecidos os povos do despotismo sacerdotal ou real (...). (GARRETT, 1963, p.817-818) 
A tarefa histórica de Napoleão para Garrett, como nos deixa inferir o trecho acima, esteve associada a um conjunto de ideias coletivas que o ímpeto de conquistas do general corso ajudou a despertar no povo europeu, adormecido durante séculos sob o subjugo das monarquias absolutista e do obscurantismo religioso. A ação militar de Bonaparte fez aflorar o protagonismo histórico de uma esfera social acostumada apenas a obedecer a ordens e, por um breve momento, também sintetizou, dentro de uma perspectiva romântica, o espírito de liberdade política e justiça social desses setores sociais explorados pelos privilégios de nascimento e outros mais do chamado Antigo Regime.

A força do protagonismo histórico de Napoleão e a mitificação de sua figura e ações no imaginário político e na literatura europeia talvez tenham despertado nos romancistas portugueses uma tendência em construir personagens guiados por uma inabalável energia e condicionados à concretização de suas paixões. Afinal, a trajetória meteórica de Napoleão, encerrada de maneira trágica na ilha de Santa Helena, objetivou, para o nascente romance histórico oitocentista, a via-crúcis que todo herói romântico deveria percorrer.

Na narrativa ficcional e historiográfica de Alexandre Herculano facilmente encontramos personagens caracterizados dentro dessas tonalidades trágicas. Para o autor português, que contribuiu para sedimen- 
tar o Romantismo em terras lusitanas, nas suas leituras e interpretações históricas de Portugal ganharam destaque valores como a bravura guerreira dos antigos fidalgos portugueses e seu ímpeto protagonista. Elementos morais ausentes, de acordo com a visão de Herculano, na decadente nobreza cortesã formada a partir dos excessos materiais advindos das conquistas marítimas portuguesas.

Tanto Eurico quanto Vasco, personagens centrais dos romances históricos Eurico, o presbítero e $O$ Monge de Cister, agem de acordo com sua inflexível e impetuosa vontade, se afirmam como indivíduos que não temem perigos e barreiras para a concretização de suas missões pessoais, características que se aproximam da leitura romântica construída em torno de Napoleão Bonaparte.

Num determinado escrito ligado à questão envolvendo o clero e a famosa discussão historiográfica acerca do Milagre de Ourique intitulado Considerações Pacíficas, Alexandre Herculano, dissertando sobre a legitimidade do poder real, acaba dizendo: "Não há nessas ideias (de negação da monarquia) um orgulho, uma intolerância para com os poderes da terra, que não compreenderíamos, talvez, hoje, se não tivesse vivido no nosso século uma inteligência igualmente vasta e enérgica, chamada Napoleão Bonaparte?" (HERCULANO, s/d, p. 52-53). Apesar de monarquista e liberal confesso, Herculano utiliza de uma imagem positiva para julgar o singular general corso. Deixa 
deduzido nas entrelinhas de seu exercício interpretativo histórico que, como indivíduo, Bonaparte se destacou como exemplo de inspiração a todo tipo de inércia histórica.

Dentro dos autores oitocentistas portugueses ligados, tradicionalmente, ao movimento romântico português, Camilo Castelo Branco possui uma interpretação histórica um pouco menos nebulosa e contraditória acerca de Napoleão Bonaparte. Pelo menos é o que deixa inferido no romance Livro Negro do Padre Dinis.

Esse romance de Camilo, escrito em 1855, que foi concebido após a publicação dos Mistérios de Lisboa, de 1854, possui um enredo labiríntico, mas, basicamente, aborda eventos relacionados à vida de Sebastião de Melo, o padre Dinis, ou seja, se propõe a revelar o período de juventude do protagonista mais carismático dos Mistérios de Lisboa.

O jovem Sebastião, devido a uma série de contingências do destino, vive na França aos cuidados de uma família aristocrática e é chamado de Benoit de Montfort. Cabe destacar que o contexto maior da história se passa no período da Revolução Francesa, tema histórico de grande interesse por parte de Camilo Castelo Branco e abordado, principalmente, dentro dos episódios das invasões napoleônicas em Portugal nos romances Onde Está a Felicidade? de 1856, Carlota Ângela de 1858, A Enjeitada, de 1865 e no $O$ Demónio do Ouro, de 1873-1874. 
Numa breve caracterização sobre o evento revolucionário francês, Camilo adota uma visão contrarrevolucionária comum entre os liberais portugueses, influenciados, em certa medida, pelo posicionamento ideológico de Edmund Burke no seu célebre escrito Reflexões sobre a Revolução na França de 1790, que condenava a eclosão de súbitas mudanças políticas e sociais geradoras de desordens sociais e excessos de violência.

Sabeis demasiadamente o que foi a revolução francesa, essa tempestade de sangue, vaticinada nos reinados de Luís XIV e Luís XV, e cumprida como a profecia indestrutível de uma lógica de ferro, em que vemos um rei pagar com a cabeça os desatinos que lhe vieram, em herança, dos reis passados. Se não conheceis os pormenores dessa luta, cuja história contrista e horroriza, nem por isso vos obrigo a estudá-la como preparatório para a inteligência deste romance. (...). Eu respingarei, nesta vasta seara juncada de cadáveres, as atrocidades (se é que não foram decretos providenciais, como por aí nos dizem ilustres personagens que deduzem do cristianismo a Revolução Francesa, e graduam na mesma escala Cristo e Robespierre, os apóstolos e os girondinos) as atrocidades, dizia eu, que se acham obrigados ao desenvolvimento do romance. (CASTELO BRANCO, 2007, p. 74)

Apesar de endossar uma tradicional visão liberal negativa em relação à Revolução Francesa, em especial, ao período do Terror, Camilo promove outra perspectiva interpretativa acerca de Napoleão. 
Benoit de Montfort, motivado por uma vingança de família e pelos ideais aristocráticos defendidos pelo grupo social em que estava inserido, parte para o campo de batalha a fim de combater o exército revolucionário francês. 0 ímpeto e a coragem de Benoit, conduzidos por um orgulho fidalgo e uma energia aristocrática, ainda não corrompida pela sociedade cortesã, fazem com que o rapaz seja designado numa missão praticamente suicida, mas repleta de glória: matar Napoleão Bonaparte. Contudo, a missão fracassa porque Benoit de Montfort fica encantado com a figura carismática do general corso.

Napoleão abraçara o moço, que tremia sacudido pela eletricidade das suas últimas palavras. Montfort, que, no delírio da falsa glória, se fizera homicida voluntário, foi instantaneamente acessível ao entusiasmo, ao delírio de uma outra glória, que parecia projetar-se-lhe do olhar ardente de Bonaparte. A sua resposta ao brado do general foi o silêncio, e esse silêncio era a única resposta que poderia dar-lhe o moço de dezoito anos, sopitado sob influência de uma espécie de terror santo. Quis fingir ânimo varonil; mas atraiçoaram-no as comoções da sua idade. Napoleão compreendeu-o. Tomou essa postura de braços cruzados que o acompanha na imoralidade do busto, e disse: - Olhai que nos esperam, meu ajudante de ordens. (...). Benoit de Montfort esporeava um fogoso cavalo andaluz, no estado-maior de Napoleão. (CASTELO BRANCO, 2007, p. 101)

A partir do encontro do ardente jovem com Napoleão, Benoit passa a combater ao lado dos franceses e 
se torna um entusiasta fiel de seus ideais revolucionários.

Essa visão de excepcionalidade envolvendo a figura do general corso, capaz de fascinar com poucas palavras um jovem incauto como Benoit e que surge apenas como personagem transitória e sem muita importância no enredo dessa obra de Camilo, pode ser notada em outro autor português, outrora de certo sucesso editorial, mas atualmente desconhecido do grande público, Antônio Maria de Campos Júnior.

\section{0 Napoleão de Campos Júnior}

Antônio Maria de Campos Júnior (1850-1917) foi um autor português, nascido nos Açores, que escreveu uma série de romances históricos, lançados, originalmente, em jornais e revistas, e que posteriormente, após a morte do autor, foram publicados pela Editora Romano Torres.

Além de ser militar, e da preocupação que manifestou com os caminhos políticos de seu tempo, objetivada na sua filiação ao Partido Regenerador português, Campos Júnior também se destacou como escritor e jornalista, atuando como redator nos jornais Diário de notícias, Revolução de Setembro, O Século e no semanário Distrito de Leiria.

A temática dos romances de Campos Júnior é variada e abarca contextos bastante distintos da história de Portugal, compreendendo acontecimentos e even- 
tos históricos tanto do século XVI quanto do período oitocentista europeu. Além disso, podemos destacar em sua obra ficcional a importância que o autor dá aos grandes personagens históricos como Camões, o Marquês de Pombal e Napoleão Bonaparte.

Essa ampla periodização histórica encontrada na obra de Campos Júnior e a preocupação em retratar figuras conhecidas da História podem transmitir ao leitor, num primeiro momento, a falsa ideia de que dentro da sua produção literária, só encontraremos uma visão superficial dos eventos históricos retratados e a inexistência de uma lógica interpretativa do passado.

Contudo, após a leitura do romance histórico A rainha-madrasta, publicado pela Ed. Romano Torres em 1911, que trata, de maneira geral, da disputa amorosa entre o rei D. Manuel I e seu filho mais velho, o futuro D. João III, pelo amor de D. Leonor da Áustria, pode-se constatar uma interessante construção histórica no romance que se aproxima, em muitos sentidos, da leitura histórica feita por Alexandre Herculano em sua obra ficcional e historiográfica, baseada nos princípios de valorização de uma ética fidalga guerreira e na decadência cultural da aristocracia portuguesa iniciada com o advento das Grandes Navegações.

Essa linha interpretativa da História seguida por Campos Júnior, que, não obstante, absorveu e reinterpretou, de maneira particular, outros aspectos do romance histórico oitocentista, podem ser encontrados, 
sobre muitos aspectos, no seu romance Os últimos amores de Napoleão.

Na longa lista de produções ficcionais de base históricas escritas por Campos Júnior, dois romances tratam, especificamente, das guerras napoleônicas. Cronologicamente foram publicados, em 1900, Os últimos amores de Napoleão, e, logo depois, em 1903, A filha do Polaco, sendo que o primeiro romance alcançou o número de duas edições entre 1900 e 1947, e o segundo, com maior sucesso editorial, quatro edições entre 1903 e $1960^{1}$.

Apesar do maior número de publicações do romance $A$ filha do Polaco, o tema central do romance de 1900, que aborda a derrota de Napoleão Bonaparte em Waterloo e seu exílio na ilha de Santa Helena, faz mais sentido para os objetivos do presente trabalho, já que apresenta uma interpretação acerca da imagem do general corso a partir de acontecimentos posteriores ao período de apogeu do seu poder político e militar, momento histórico em que a lenda dourada e a ideia do regresso de Napoleão à França estiveram mais em voga no imaginário político europeu.

O romance Os últimos amores de Napoleão de Campos Júnior, na sua edição de 1947, possui verdadeiras proporções folhetinescas, abarcando um conjunto de quatro volumes que somam juntos, uma média de 936 páginas.

1 Informações coletadas da fonte eletrônica: worldcat.org/ identities/lccn-no92013955 (último acesso em 04/11/2018). 
Esse caudaloso escrito também é herdeiro dos enredos folhetinescos oitocentistas, possuindo inúmeras reviravoltas em sua trama, encontros súbitos e inverossímeis de personagens e uma narrativa repleta de episódios conduzidos por uma atmosfera de mistérios, segredos e disfarces. Enfim, um romance que, mesmo sendo excessivamente piegas em alguns momentos, conseguiu sintetizar estilos narrativos caros ao século XIX e abordou um tema pouco usual, o exílio de Napoleão.

0 romance, escrito em terceira pessoa, tem início em 18 de junho de 1815, data da famosa batalha de Waterloo, e o autor, nos primeiros capítulos, alterna a sua narrativa, entre a descrição e análise das conquistas de Napoleão e a apresentação da protagonista da obra, a aristocrata Laura de Santa Croce, filha do conde italiano de Santa Croce, outrora amante de Bonaparte e mãe de um filho bastardo do general.

A enumeração das campanhas napoleônicas serviu de motivo para a primeira grande interpretação da figura de Napoleão Bonaparte feita por Campos Júnior ao longo do romance. Para ele, o general corso, através de suas conquistas, superou o protagonismo histórico de Alexandre e César (CAMPOS JÚNIOR, 1947, vol.1, p. 19), e se firmou como o grande vulto do século XIX, porque com sua insaciável sede de glórias e vitórias militares acabou colocando em xeque monarquias decadentes e levou adiante os ideais da Revolução Francesa, corroborando, em certo sentido, 
com a imagem de Napoleão construída por Garrett na obra Portugal na Balança da Europa.

Mas, a despeito da onda avassaladora dessas invasões e das ambições iníquas desse novo César, a verdade era que nos relâmpagos vermelhos dos canhões e na viva cintilação das baionetas vinha um clarão da alvorada de 89 , e esse ficou pairando como luz fecundadora sobre as decrépitas autocracias. (CAMPOS JÚNIOR, 1947, vol. 1, p.20)

Antes de traçar um relato pormenorizado da campanha de Waterloo, tanto em relação à descrição da batalha em si quanto na elaboração dos diálogos travados pelas principais personagens do evento histórico, como Napoleão, Soult e Ney, o autor recupera a trajetória militar das guerras napoleônicas, estabelecendo um período de auge para as glórias de Bonaparte e os primeiros sinais de abalo do terrível exército napoleônico.

Para Campos Júnior, as campanhas militares em Portugal, principalmente a terceira, comandada por André Massena, representaram o primeiro sinal de esgotamento do exército napoleônico e revelaram ao mundo a valentia e o protagonismo do povo português.

A terceira invasão de Portugal, uma epopeia de abnegações e uma enorme tragédia de horrores sobre uma laguna de sangue e sobre um rescaldo de cinzas, foi imensamente mais desastrosa para a França napoleônica do que tinham sido as outras duas de 1808 e 
1809, a de Andoche Junot, duque de Abrantes, e a do marechal Soult, duque de Dalmácia. Foi das névoas da serra do Buçaco, na manhã daquele dia de Setembro em que Massena perdeu a sua primeira e última batalha, foi delas que provieram as primeiras neblinas ofuscadoras da estrela napoleônica. (CAMPOS JÚNIOR, 1947, vol. 1, p. 22)

Esse lento ocaso do exército de Napoleão, intensificado com a desastrosa campanha militar na Rússia, em 1812, recuperou seu antigo fervor e energia após o retorno do general corso de seu primeiro exílio em Elba, contudo a derrota em Waterloo selou o fim definitivo do outrora poderoso Império Napoleônico.

Contudo, a fidelidade em torno de Napoleão Bonaparte não esmorece com a sua prisão e seu exílio definitivo na ilha de Santa Helena. 0 poder de atração exercido pelo maior general do mundo permanece vivo em seus muitos soldados, como, por exemplo, nos irmãos João e Anatole Beauchamps, que, protegem e defendem, em muitas passagens do romance, Laura de Santa Crocce, por saberem que ela tem um filho do seu amado general.

Essa lealdade e fidelidade presentes naqueles que conheceram Bonaparte ou lutaram ao seu lado no campo de batalha são exaltados como valores éticos positivos para Campos Júnior, nos remetendo à temática da fidalguia e dos seus princípios morais, facilmente encontrados nos romances históricos de Alexandre Herculano e, num grau menor, também na ficção de Camilo. 
A coragem e a intrepidez de espírito são constantes nos soldados napoleônicos do romance de Campos Júnior, e a maneira como são traduzidas em palavras nos remetem às construções narrativas que visavam à busca do efeito do sublime como encontradas, em muitos momentos, na prosa de Herculano.

De uma coluna inglesa, mais avançada, um general se adiantou gritando num francês áspero, gutural: - Granadeiros, rendei-vos!

Corre para a face do quadrado donde o inglês o podia ouvir melhor, Cambronne, já sem chapéu porque uma bala lho levara, o capote ao ombro, o braço numa atitude trágica, gritou fremente, debruçando-se daquela muralha de homens: - A Velha Guarda morre, mas não se rende!

Num grito soberbo todo o quadrado aplaudiu esta frase, que valia uma epopeia. (...). Tinham um aspecto fantástico de lenda aqueles esquadrões e aqueles regimentos, que se moviam, recortados pelo dobro, numa pálida penumbra. Às vezes, com o céu mais desanuveado o luar batia em cheio no quadrado semi-morto e então os soberbos veteranos pareciam maiores, altos como ciprestes. (CAMPOS JÚNIOR, 1947, vol.1, p. 66)

A jovem aristocrata Laura de Santa Crocce, uma das inúmeras amantes que Napoleão teve em sua vida, talvez sintetize essa vontade inabalável e essa intrepidez de espírito própria dos valores de uma hipotética fidalguia. Sua devoção e admiração por Bonaparte faz com que tenha força para enfrentar uma série de obstáculos impostos pelo destino, como a louca paixão de Mauricio Delaborde, ex-soldado 
francês que durante toda a narrativa a atormenta e a persegue, e o arriscado plano que arquiteta para encontrar Napoleão na ilha de Santa Helena (CAMPOS JÚNIOR, 1947, vol. 1, p. 231).

Utilizando recursos advindos dos romances históricos e folhetinesco do período oitocentista Campos Júnior faz com que Laura, portando uma identidade falsa, acompanhada de sua tia, Margarida Kilney, e de um misterioso homem chamado George Hudson, consiga realizar o seu intuito de chegar até Santa Helena e ter seu encontro com o general corso.

Napoleão Bonaparte, no seu exílio de Santa Helena, será representado por Campos Júnior tanto na sua esfera privada, com a descrição em detalhes de sua vida em Longwood, local de sua residência na ilha, das relações que mantém com seu círculo de fiéis amigos e ex-combatentes de seu exército, que escolheram partir para o exílio junto de seu querido general, quanto no seu aspecto humano, revelando seus sentimentos, valores morais e angústias.

Para traçar essa segunda interpretação da imagem de Napoleão, o autor se utilizou de fontes documentais do período, como o livro de memórias do médico 0'Meara que conviveu com Bonaparte em Santa Helena e também foi aproveitado como personagem no romance.

No seu cotidiano, o antigo Imperador éapresentado como um homem repleto de atos de generosidade para aqueles que o cercam, disposto a receber e a ou- 
vir admiradores vindos de várias partes da Europa, um homem transparente em suas ações, que chora e lamenta quando lembra seus antigos tempos de glória e quando é tomado de angústia por ser obrigado a viver longe do Rei de Roma, filho que teve com a Imperatriz Maria Luísa.

Seus súbitos rompantes de raiva e orgulho, geralmente são motivados por visitas indesejáveis que recebe em Longwood, como a de representantes políticos da Santa Aliança e de inimigos declarados, como o marquês de Montchenu, e, principalmente, do governador de Santa Helena, o general inglês Hudson Lowe.

Tanto Hudson Lowe quanto o marquês de Montchenu representam o oposto de Napoleão Bonaparte no romance, configurando-se quase como seus antípodas históricos. 0 primeiro é destacado por Campos Júnior como um general inútil que nunca comandou um exército e a única glória de sua tediosa e iníqua existência foi ser carcereiro de Napoleão (CAMPOS JÚNIOR, 1947, vol.II, p. 46). Já o segundo, o marquês de Montchenu, sintetiza a parasitária nobreza cortesã francesa, artificial em suas ações, repleta de vícios e excessivamente orgulhosa de sua condição superior de nascimento.

(...) Bonaparte vota-lhe o mais profundo desprezo. Montchenu foi pajem de Luís XV, entrou no exército antes da Revolução, acompanhou os Bourbons no exílio e deu um salto de acrobata na sua carreira mili- 
tar, quase lendária por obscura. - General de carroça como lhe chamou o mestre supremo da guerra. (CAMPOS JÚNIOR, 1947, vol.II, p. 81)

A representação positiva que Campos Júnior elabora de Napoleão Bonaparte é construída, ao longo da narrativa, com base na descrição de episódios que só realçam o caráter excepcional do ex-Imperador francês, seja através de suas atitudes e palavras, sintonizadas por uma limpidez e transparência de caráter, ou por meio da atração natural que sua figura causa em homens e mulheres, além, é claro, da comparação que o autor estabelece entre o general corso e outras personagens da narrativa, como Hudson Lowe e o marquês de Montchenu.

Dessa forma, não há como não citar a personagem grotesca de John Jones, o rico comerciante inglês, vendedor de manteigas, que empreende uma arriscada viagem até a Ilha de Santa Helena, ao lado da sua também pitoresca família, para se tornar fornecedor majoritário de sua iguaria a Napoleão Bonaparte.

Talvez Campos Júnior, quando pensou em John Jones, tinha por finalidade ridicularizar a figura do burguês, ávido por dinheiro e excessivamente apegado às aparências e artificialidades da nascente sociedade capitalista industrial. 0 comerciante de manteigas é o personagem que, assim como outros, cumpre no romance o papel de potencializar a imagem do mito 
heroico de Napoleão e dos valores românticos que ele encarnava.

Um grande industrial e um grande desequilibrado, Jones acreditava na sua estrela propícia como Napoleão acreditara naquela que se lhe sumira, e acalentava em si, fervorosamente, a ideia suprema de ligar o seu nome ao do assombroso exilado, metendo um reflexo de Austerlitz na sua fábrica de Cork e boiando ele pelos mares da História escarranchado num barril da sua famosa manteiga. (...). 0 ridículo era o seu condão e a sua fatalidade. (CAMPOS JÚNIOR, 1947, vol.II, p. 206-207)

A representação de Napoleão traçada por Campos Júnior só corrobora, ainda mais, o diálogo do autor com a construção da lenda dourada ligada ao ex-imperador francês com a abordagem, no romance, de um plano de fuga, envolvendo o general corso, arquitetado por admiradores e entusiastas de Bonaparte ligados à questão da Independência da Irlanda.

Esse episódio do romance, com ares folhetinescos, possui bases históricas reais se lembrarmos de que a historiografia em torno do período napoleônico aponta para a existência de documentos que mencionam planos de fuga de Napoleão Bonaparte da ilha de Santa Helena, arquitetados por ex-soldados napoleônicos e admiradores do general corso, para destinos tão diferentes como Estados Unidos e Brasil.

O homem que chegou com Laura e sua tia a Santa Helena, chamado George Hudson, é na verdade, um 
revolucionário irlandês que quer libertar Napoleão Bonaparte para que ele o ajude na luta de independência da Irlanda. Seu plano, que obviamente dá errado, tinha o financiamento da rica tia de Laura, Margarida Kilney, que contava com o apoio de ex-soldados napoleônicos que desembarcariam na ilha armados para libertar Napoleão, e também tinha um grande aliado próximo de Bonaparte, o seu médico particular Barry Edward O’Meara, personagem também histórico e que de fato era irlandês ${ }^{2}$.

- Não será assim, O’Meara - volveu-lhe calorosamente (George Hudon) - Não há de ser. Por detrás desses amores romanescos de uma devaneadora, lidaremos nós devotadamente pela nossa gloriosa obra reivindicadora. Reacendendo na alma da França o sentimento do desforço e a ânsia da glória, levando-lhe daqui o Homem para que a lenda napoleônica ressurja, teremos conquistado um poder que nos ajude a ressurgir a Irlanda e será este o prêmio único de todo o nosso esforço. Isto, que parece agora a quimera de algumas dezenas de visionários, será aqui a meses a cruzada redentora de uma infortunada nacionalidade. A nossa. E a tarefa inicial, a tarefa maior pertence-nos, $\mathrm{O}^{\prime} \mathrm{Me}-$ ara! Há de vir das nossas almas a luz criadora, a luz miraculosa para o ressurgimento da nação mártir, ou não ressurgirá nunca! (CAMPOS JÚNIOR, 1947, vol.II, p. 52)

2 0 livro de memórias de 0’Meara, "Napoleão no exílio" conhecido também como "A Voz de Santa Helena" de 1822, fonte histórica que serviu de base para a elaboração do romance histórico de Campos Júnior, ficou famoso, entre outros aspectos, por acusar Sir Hudson Lowe, governador de Santa Helena, de maltratar, continuamente, o ex-imperador francês. 
Esses episódios do romance histórico de Campos Júnior analisados rapidamente no presente texto, revelam a instigante representação literária de $\mathrm{Na}$ poleão Bonaparte elaborada pelo autor com base na herança da lenda dourada ou rosa legada por um conjunto de construções historiográficas e literárias portuguesas oitocentistas e que estiveram em sintonia com o espaço cultural comum europeu. Para Campos Júnior e para outros tantos autores e intelectuais europeus, o famoso general corso, ou pelo menos, a sua construção como personagem histórica esteve ligada à eterna esperança por um mundo mais justo e liberto dos inúmeros privilégios sociais determinados apenas pelo nascimento. "Decaído, prisioneiro, abandonado, aquele homem pequeno tem ainda para os outros homens uma estatura colossal como se o vissem numa perspectiva de sonho" (CAMPOS JÚNIOR, 1947, vol.II, p. 122). 


\section{Referências}

BERBEL, Márcia Regina. Deputados do Brasil nas Cortes Portuguesas de 1821-1822: Um Estudo sobre o conceito de Nação. Tese (Doutorado em História) - FFLCH/USP. São Paulo, 1997.

BRANCO, Camilo Castelo. Livro Negro de Padre Dinis. Lisboa: Parceria A.M. Pereira, 2007.

CAMPOS JÚNIOR, Antônio. Os últimos amores de Napoleão. Lisboa: Torres Editores, 4 volumes, 1947.

FALBEL, Nachman. Fundamentos históricos do Romantismo. In: GUINSBURG, J. (Org). O Romantismo. São Paulo: Perspectiva, 2011.

GARRETT, Almeida. Portugal na Balança da Europa. In: GARRETT, Almeida. Obras de Almeida Garrett (vol.1). Porto: Lello \& Irmãos Editores, 1963.

HERCULANO, Alexandre. A batalha de Ourique - Considerações pacíficas. In: HERCULANO, Alexandre. Opúsculos Tomo III (Controvérsias e Estudos Históricos). Lisboa: Livraria Bertrand, s/d.

MARINHO, Maria de Fátima. Quem tem medo dos franceses? Carnets, Invasions \& Évasions. La France et nous; nous et la France, numéro spécial automne-hiver. Universidade de Aveiro, 2011-2012, p. 45-61. Disponível em http://carnets.web.ua.pt. Acesso em: 21 mai. 2020.

NEVES, Lúcia Maria Bastos Pereira das. Napoleão Bonaparte: imaginário e política em Portugal. São Paulo: Alameda, 2008. 